\title{
KEDUDUKAN AHLI WARIS ATAS PEMBAGIAN HARTA PENINGGALAN DALAM PERKAWINAN MENURUT PERSPEKTIF HUKUM POSITIF (STUDI KASUS PUTUSAN NOMOR 239/PDT.G/2015/PN.JKT.PST)
}

\author{
Rahmatika \\ Rumah Sehat Holistik Indonesia, Kota Depok \\ Tikaochi9@gmail.com
}

\begin{abstract}
Abstrak
Permasalahan tentang kedudukan anak yang dilahirkan sebelum perkawinan orang tuanya dilakukan berakibat terhadap pembagian harta peninggalan kepada ahli waris seperti terjadi pada kasus putusan nomor 239/Pdt.G/2015/PN.JKT.PST. Dalam penelitian ini permasalahan yang diangkat ialah bagaimana kepastian dan akibat hukum terhadap kedudukan ahli waris dalam perkawinan menurut hukum positif pada kasus putusan nomor 239/Pdt.G/2015/PN.JKT.PST dan bagaimana pertimbangan hukum majelis hakim dalam putusan nomor 239/Pdt.G/2015/PN.JKT.PST yang mengabulkan gugatan penggugat menurut hukum yang berlaku. Untuk menjawab permasalahan tersebut digunakan metode penelitian hukum normatif yang bersifat deskriptif dengan pendekatan yuridis normatif berdasarkan data sekunder dari bahan hukum primer, sekunder dan tertier. Sehingga didapat simpulan bahwa kepastian dan akibat hukum terhadap kedudukan ahli waris dalam perkawinan menurut perspektif hukum positif pada kasus putusan nomor 239/Pdt.G/2015/PN.JKT.PST belum tercapai kepastian hukum dan berakibat dengan ketidaksesuaian kedudukan ahli waris pada perkawinan kedua yang seharusnya menjadi anak luar kawin walaupun perkawinan yang dilakukan oleh kedua orangtuanya dinyatakan sah secara hukum karena tercatat pada kantor pencatatan sipil berdasarkan Kutipan Akta Perkawinan yang ada. Sedangkan pertimbangan hukum majelis hakim dalam kasus putusan nomor 239/Pdt.G/2015/PN.JKT.PST menyatakan sahnya perkawinan kedua yang terjadi selama masa perkawinan pertama akan menimbulkan akibat hukum terhadap kedudukan anak yang dilahirkan dalam perkawinan kedua tersebut sebagai anak yang dilahirkan di luar perkawinan menurut Undang-Undang Perkawinan yang dilahirkan di luar perkawinan hanya mempunyai hubungan keperdataan dengan ibunya dan keluarga ibunya saja. Maka anak-anak dari perkawinan kedua tidak berhak mewaris mengingat harta warisan
\end{abstract}


merupakan harta peninggalan pewaris dari ayahnya yang selanjutnya akan berakibat kepada pembagian waris.

Kata kunci: Kedudukan Ahli Waris, Anak Luar Kawin.

\begin{abstract}
The child-born-outside-marriage position causes problems in inheritance division to the heir as what happened in the verdict case number 239/Pdt.G/2015/PN.JKT.PST. This study issue is the law certainty and impacts on the heir position in the marriage by the positive law and how the judge law consideration in this case. The study method used is a descriptive normative legal analysis with normative legal approach from the secondary data of primary, secondary and tertiary law materials. Therefore, the conclusion is the law certainty of the heir position has not been achieved though the parents' marriage is legal in Civil Registry Office based on the Marriage Certificate. Meanwhile, the judges state the second marriage legality in the first marriage period will position the child only has civil relation with the mother and her family that makes him has no rights on his father's inheritance which impacts the inheritance division.
\end{abstract}

Keywords: Heir Position, Outside-Marriage Child

\title{
PENDAHULUAN
}

Pengaturan tentang keluarga dan perkawinan pada Pasal 28 B ayat (1) UndangUndang Dasar 1945 menyebutkan bahwa setiap orang berhak membentuk keluarga dan melanjutkan keturunan melalui perkawinan yang sah.

KUHPerdata yang berlaku di Indonesia hanya terdapat satu pasal saja yang menjadi ketentuan umum tentang perkawinan, yaitu pasal 26 yang menyatakan bahwa "undangundang memandang soal perkawinan itu hanya dalam hubungan-hubungan perdata". ${ }^{1}$

Tujuan perkawinan menurut hukum perdata adalah membentuk keluarga yang bahagia sampai kepada keturunannya seperti tercantum dalam Pasal 279 KUHPerdata yang menyebutkan: "Dengan cara yang sama dan menurut ketentuan-ketentuan yang sama pula seperti termuat dalam pasal-pasal yang lalu, anak-anak yang telah meninggal dunia dan meningkatkan keturunannya, boleh disahkan, pengesahan mana adalah demi kebahagiaan sekalian keturunan itu." ${ }^{2}$ Maksud keabsahan dalam pasal tersebut adalah tentang

\footnotetext{
${ }^{1}$ R. Subekti dan R. Tjitrosudibio, Kitab Undang-Undang Hukum Perdata, (Jakarta: PT. Pradya Paramita, 2006), hlm.8.

${ }^{2}$ Ibid., hlm. 69.
} 
pengesahan status anak luar kawin, karena pasal tersebut termasuk ke dalam Bagian Ke Dua Buku Ke Satu Tentang Orang KUHPerdata.

Sehubungan dengan soal keabsahan status anak luar kawin disini adalah bukan tentang anak zinah atau anak sumbang, namun dapat diartikan sebagai anak yang dilahirkan diluar perkawinan orang tuanya tetapi sudah diakui menurut ketentuan undang-undang yang berlaku sebelum perkawinan orang tuanya terjadi dan pengakuan tersebut dilakukan dalam akta perkawinan sendiri. ${ }^{3}$

Hukum waris dalam ilmu hukum merujuk pada ketentuan yang diatur dalam KUHPerdata. Pengaturan mengenai hukum waris tersebut dapat dijumpai dalam pasal 830 sampai dengan pasal 1130 KUHPerdata. Meski demikian, pengertian mengenai hukum waris itu sendiri tidak dapat dijumpai pada bunyi pasal-pasal yang mengaturnya dalam KUHPerdata tersebut.

Hukum waris menurut konsepsi hukum perdata barat yang bersumber pada Burgerlijk Wetboek, merupakan bagian dari hukum harta kekayaan. Oleh karena itu, hanyalah hak dan kewajiban yang berwujud harta kekayaan yang merupakan warisan dan yang akan diwariskan. Hak dan kewajiban dalam hukum publik, hak dan kewajiban yang timbul dari kesusilaan dan kesopanan tidak akan diwariskan, demikian pula halnya dengan hak dan kewajiban yang timbul dari hubungan hukum keluarga, ini juga tidak dapat diwariskan.

Hukum waris merupakan salah satu bagian dari hukum perdata secara keseluruhan dan merupakan bagian terkecil dari Hukum Keluarga. Hukum waris yang ada dan berlaku di Indonesia sampai saat ini masih belum merupakan unifikasi hukum. Untuk itu hingga kini peraturan masalah waris masih belum terdapat keseragaman. Apabila memperhatikan pengaturan yang berbeda-beda, maka dapat diketahui baik perbedaan maupun persamaannya dan para ahli waris, baik Hukum Waris Perdata maupun Hukum Waris Islam. ${ }^{4}$

Hubungan hukum antar manusia selaku subyek hukum, harta merupakan obyek hukum yang menjadi sasaran pokok. Adapun harta dalam perkawinan mempunyai peran penting karena dengan harta tersebut, maka dapat terpenuhinya kebutuhan-kebutuhan keluarga.

\footnotetext{
${ }^{3}$ Ibid. Pasal 272.

${ }^{4}$ Retno Wulan Sutantio, Wanita dan Hukum, (Bandung: Alumni, 1979), hlm. 84.
} 
Di Indonesia, belum ada suatu keseragaman penerapan hukum waris yang berlaku secara nasional. Terdapat 3 (tiga) hukum waris yang berlaku di Indonesia, yaitu hukum waris adat, hukum waris Islam, dan hukum waris perdata. Masing-masing mempunyai aturan mengenai waris yang berbeda-beda. Permasalahan mengenai kewarisan banyak sekali di jumpai dalam kehidupan sehari-hari. Salah satu masalah yang biasanya timbul adalah permasalahan mengenai kedudukan ahli waris sebagai anak yang lahir diluar perkawinan atau sebelum perkawinan terjadi.

Berangkat dari pembahasan mengenai permasalahn tersebut, peneliti menganggap penting untuk dapat mengkaji lebih dalam dan menganalisis permasalahan tentang kedudukan ahli waris sebagai anak diluar perkawinan dan pembagian harta peninggalan pewaris menurut hukum yang berlaku di Indonesia seperti yang terjadi pada kasus putusan Nomor 239/Pdt.G/2015/PN.JKT.PST.

Sehingga permasalahan yang diangkat dalam penulisan ini adalah:

1. Bagaimana kepastian dan akibat hukum terhadap kedudukan ahli waris dalam perkawinan menurut perspektif hukum positif pada kasus putusan nomor 239/Pdt.G/2015/PN.JKT.PST ?

2. Bagaimana pertimbangan hukum majelis hakim dalam putusan nomor 239/Pdt.G/2015/PN.JKT.PST yang mengabulkan gugatan penggugat menurut hukum yang berlaku?

\section{METODE}

Jenis penelitian ini dapat digolongkan sebagai penelitian hukum normatif yang bersifat deskriptif. penelitian hukum normatif atau penelitian hukum kepustakaan menurut Soerjono Soekanto dan Sri Mamudji dalam bukunya yang berjudul Penelitian Hukum Normatif, Suatu Tinjauan Singkat, merupakan penelitian hukum yang dilakukan dengan cara meneliti bahan pustaka atau data sekunder belaka ${ }^{5}$. Kemudian pendekatan penelitiannya menggunakan pendekatan yuridis normatif yaitu suatu penelitian yang membahas tentang asas-asas hukum terhadap hukum positif tertulis, antara lain dengan memilih dan menganalisis pasal-pasal dalam peraturan perundang-undangan yang berkaitan dengan perkawinan dan akibat hukumnya. ${ }^{6}$

\footnotetext{
${ }^{5}$ Soerjono Soekanto dan Sri Mamudji, Penelitian Hukum Normatif: Suatu Tinjauan Singkat, Cet. Ke-15, (Jakarta: PT. Raja Grafindo Persada, 2013), hlm. 13.

${ }^{6}$ Bistaman, Tinjauan Yuridis Pembagian Waris Bagi Ahli Waris Yang Berbeda Agama dengan Pewaris ditinjau dari Hukum Islam dan Hukum Perdata.
} 
Penelitian yuridis normatif pada penelitian ini menggunakan data sekunder yang terdiri dari:

1. Bahan hukum primer

yaitu "bahan-bahan hukum yang mengikat"7 seperti Undang-Undang Dasar 1945), Undang-Undang Undang-Undang Perkawinan), KUHPerdata, Peraturan Pemerintah Republik Indonesia No. 54 Tahun 2007 tentang Pelaksanaan Pengangkatan Anak, UndangUndang Republik Indonesia No. 48 Tahun 2009 tentang Kekuasaan Kehakiman (untuk selanjutnya disebut Undang-Undang Kekuasaan Kehakiman).

2. Bahan hukum sekunder

yaitu "bahan-bahan yang erat hubungannya dengan bahan hukum primer dan dapat membantu menganalisis dan memahami bahan hukum primer" ${ }^{8}$, seperti buku yang ditulis oleh para ahli dibidang hukum yang dapat dijadikan sebagai pendapat dari para ahli, artikel, jurnal, skripsi, dan penulisan ilmiah lainnya.

3. Bahan hukum tersier

yaitu "bahan-bahan yang memberikan informasi tentang bahan primer dan bahan sekunder." , misalnya kamus hukum, ensiklopedi, indeks komulatif dan lainnya. ${ }^{10}$

Setelah seluruh bahan hukum yang diperlukan terkumpul, maka untuk menganalisisnya menggunakan metode pengelolaan data dalam bentuk kualitatif karena data yang disajikan tidak menggunakan angka-angka dan hanya menguraikan saja. Analisa data kualitatif yaitu prosedur dari penelitian yang menghasilkan data deskriptif analitis seperti yang telah disampaikan dalam tujuan penelitian yang relevan secara tertulis. ${ }^{11}$ Data penelitian yang bersifat deskriptif yaitu memberikan gambaran mengenai persoalanpersoalan apa yang terjadi terhadap objek penelitian dengan menghadirkan fakta kasus, fakta hukum, dan penegakan hukumnya itu sendiri pada penelitian ${ }^{12}$.

${ }^{7}$ Ibid., hlm. 13.

${ }^{8}$ Yamin dan Utji Sri Wulan Wuryandari, Nukilan: Metode Penelitian Hukum, (Jakarta: Universitas Pancasila, 2014), hlm. 29.

${ }^{9}$ Ibid.

${ }^{10}$ Ibid.

${ }^{11}$ Sri Mamudji, et.al., Metode Penelitian dan Penulisan Hukum, Cet. Ke-1, (Jakarta: Badan Penerbit Fakultas Hukum Universitas Indonesia, 2005), hlm. 67.

${ }^{12}$ Hadari Nawawi, Metode Penelitian Sosial, (Yogyakarta: Gadjah Mada University Press, 2007), hlm. 33. 


\section{HASIL DAN PEMBAHASAN}

\section{Kasus Posisi}

Dian Wahyu Rahmi, Tn. Rudy Djajasiaputra, Ny. Rosana Riyadi, Ny. Inneke Riyadi, SE, dan Ny. Vonny Riady. Sedangkan yang menjadi tergugat dalam putusan tersebut terdiri dari 3 (tiga) orang yaitu Ny. Theresia Irawaty Alias Jong Moij Jin, Tn. Dedy Riyadi dan Ny. Rosa Ria Riyadi.

Dalam hal ini yang menjadi objek sengketa dalam putusan tersebut terdiri dari 4 (empat) bidang tanah yang kesemuanya tercatat atas nama Surya Riyadi dan sejumlah saham senilai Rp. 250.000.000,- (dua ratus lima puluh juta rupiah) atas nama Surya Riyadi di PT. Jombang Agung Riyadi.

Berkaitan dengan putusan tersebut, Almarhum Surya Suryadi selaku Pewaris semasa hidupnya telah menikah sebanyak 3 (tiga) kali. Perkawinan pertama Pewaris dengan istri pertamanya yang beragama Katholik bernama Almh. Caecilia Winny Wiardi (Caecilia Tan Siok Hiu) dilangsungkan secara Katolik di Gereja Santo Paskalis, Jakarta Pusat pada tanggal 9 April 1967. Dan dari perkawinan pertamanya tersebut melahirkan keturunan 4 (empat) orang anak, yaitu: Rudi Djajasiaputra lahir pada tanggal 25 Oktober 1967, Rosana Riyadi lahir pada tanggal 28 Mei 1969, Inneke Riyadi lahir pada tanggal 28 Februari 1972, dan Vonny Riyadi lahir pada tanggal 9 Maret 1973, kesemuanya adalah beragama Katholik.

Pada perkawinan kedua, Almarhum Surya Suryadi menikah dengan dengan Theresia Irawati yang juga beragama Katholik, pada tanggal 22 Juli 1980, dan tercatat di Pencatatan Sipil Jakarta serta memiliki 2 (dua) orang anak yaitu Dedy Riyadi yang beragama Islam lahir pada 30 November 1973 dan Rosa Royadi yang beragama Katholik lahir pada tanggal 4 Juni 1975. Perkawinan kedua tersebut terjadi dalam masa perkawinan pertama belum berakhir baik karena pembatalan atau putusnya perkawinan berdasarkan perceraian.

Sementara pada perkawinan ketiga yang dilakukan secara Agama Islam oleh Almarhum Surya Suryadi dengan Dian Wahyu Rahmi di Kantor Urusan Agama Kecamatan Karang Anyar Propinsi Jawa Timur pada tanggal 30 Desember 2011, namun tidak memiliki keturunan. Dan pada saat perkawinan ketiga berlangsung keduanya beragama Islam.

\section{Kepastian Dan Akibat Hukum Terhadap Kedudukan Ahli Waris Dalam Perkawinan Menurut Perspektif Hukum Positif Pada Kasus Putusan Nomor 239/Pdt.G/2015/PN.JKT.PST}

Dalam hal pengertian perkawinan tersebut terlihat jelas jelas perkawinan terjadi antara seorang pria dengan seorang wanita yang menganut asas monogami. Selain itu, berdasarkan pengertian perkawinan tersebut terdapat tujuan yang akan dicapai yaitu 
membentuk keluarga (rumah tangga) yang bahagia dan kekal. Tujuan membentuk keluarga (rumah tangga) yang bahagia dan kekal maksudnya bahwa perkawinan dilakukan satu kali dengan prinsip kekal abadi tanpa ada perceraian.

Berdasarkan pengertian perkawinan tersebut bila dikaitkan dengan kasus yang terjadi terhadap perkawinan kedua yang dilakukan oleh pewaris dengan Tergugat I maka hubungan perkawinan diantara keduanya diragukan keabsahannya. Pada perkawinan kedua tersebut memiliki bukti Kutipan Akta Perkawinan No. 2321/1980 tertanggal 22 Juli 1980 yang dikeluarkan oleh Pegawai Luar Biasa Pencatat Sipil Jakarta, dan dilegalisir di Pengadilan Negeri Jakarta Timur tertanggal 23 Juli 1980 dibawah register No. 67/TIM/Leg/1980, menurut peneliti perkawinan tersebut tidak sah, mengingat antara Pewaris dan Tergugat II karena terjadi perkawinan kedua di dalam masa perkawinan pertama.

Hal tersebut karena perkawinan kedua dilakukan tanggal 22 Juli 1980 pada saat perkawinan pertama yang terjadi tanggal 9 April 1967, belum berakhir baik karena perceraian, pembatalan maupun kematian dari isteri pertama. Hal tersebut terbukti bahwa sampai dengan meninggalnya isteri pertama pada tanggal 05 Desember 2000 berdasarkan Surat Kutipan Akta Kematian No. 16/JT/I/2001 tanggal 10 Januari 2001, perkawinan pertama tersebut tidak putus baik karena perceraian maupun pembatalan. Dan memang dari perkawinan pertama ini terdapat kejanggalan bahwa perkawinan tersebut baru disahkan dengan Surat Perkawinan Keuskupan Agung Jakarta pada tanggal 15 Mei 2013 padahal pada saat itu isteri pertama Pewaris telah meinggal dunia. Namun, hal tersebut menurut penulis dapat diterima mengingat perkawinan pertama dilakukan sebelum Undang-Undang Perkawinan diberlakukan maka perkawinan dinyatakan sah selama dijalankan menurut peraturan-peraturan lama. Hal itu sesuai dengan Pasal 64 yang menyatakan: "untuk perkawinan dan segala sesuatu yang berhubungan dengan perkawinan yang terjadi sebelum Undang-Undang Perkawinan ini berlaku yang dijalankan menurut peraturan-peraturan lama, adalah sah."13

Selain itu, alasan lain peneliti berpendapat perkawinan pertama tersebut sah adalah karena pendaftaran perkawinan yang dilakukan pada tanggal 15 Mei 2013 atau setelah perkawinan terjadi dengan kondisi isteri pertama meninggal tidak dapat dipermasalahkan selama pewaris pada saat itu masih hidup artinya pewaris berhak melakukan permohonan pengesahan perkawinannya yang pertama karena sesuatu hal.

\footnotetext{
${ }^{13}$ Indonesia (a), Pasal 64.
} 
Menurut peneliti perkawinan kedua Pewaris dengan Tergugat I tidak sah karena terjadi perkawinan kedua di dalam masa perkawinan pertama. Hal tersebut terbukti bahwa perkawinan kedua Pewaris dengan Tergugat I dilakukan pada tanggal 22 Juli 1980 yang pada saat itu isteri pertama pewaris kondisinya masih hidup. Walaupun terhadap perkawinan kedua tercatat pada Pencatatan Sipil di Jakarta Kutipan Akta Perkawinan No. 2321/1980 tertanggal 22 Juli 1980 yang dikeluarkan oleh Pegawai Luar Biasa Pencatat Sipil Jakarta, dan dilegalisir di Pengadilan Negeri Jakarta Timur tertanggal 23 Juli 1980 dibawah register No. 67/TIM/Leg/1980. Namun bukti pencatatan perkawinan kedua patut dijadikan bahan pertimbangan majelis hakim, mengingat menurut Undang-Undang Perkawinan hanya menganut asas perkawinan monogami dan kalaupun perkawinan tersebut putus hanya ada 3 alasan yaitu kematian, perceraian dan keputusan pengadilan. Sementara ketiga alasan putusnya perkawinan tidak dibuktikan secara tertulis di dalam persidangan dengan kata lain majelis hakim kurang teliti dalam hal memeriksa alat bukti surat.

Sehingga menurut peneliti bahwa berdasarkan uraian diatas, perkawinan kedua juga dapat dikatakan tidak memenuhi unsur atau konsepsi perkawinan menurut pendapat Wahyono Darmabrata yang telah dijabarkan pada Bab II yaitu unsur ketiga dan unsur keempat. Selain itu, perkawinan kedua dikatakan tidak sah menurut penulis karena perkawinan kedua yang terjadi antara pewaris dengan Tergugat I tersebut melanggar asasasas perkawinan yaitu asas perkawinan kekal dan asas perkawinan monogami.

Perkawinan ketiga pewaris dengan Penggugat I merupakan perkawinan yang sah berdasarkan Pasal 2 ayat (1) dan ayat (2) karena perkawinan tersebut dilakukan menurut hukum masing-masing agamanya dan telah tercatat menurut peraturan perundangundangan yang berlaku. Hal tersebut dibuktikan dengan kutipan Akta Nikah Nomor: 334/06/ NI/2011 tertanggal 30 Desember 2011 yang dikeluarkan oleh Kantor Urusan Agama Gunung Anyar, Surabaya dan dilakukan secara Islam karena pada saat perkawinan dilakukan pewaris memeluk Agama Islam.

Berbicara tentang syarat sahnya suatu perkawinan, maka perkawinan kedua yang terjadi antara pewaris dengan Tergugat I tidak memenuhi syarat materiil umum menurut Wahyono Darmabrata yang telah dijabarkan pada Bab II, salah satunya adalah tidak dalam status perkawinan berdasarkan Pasal 9 ayat (1) Undang-Undang Perkawinan.

Perihal permasalahan keabsahan perkawinan kedua yang terjadi selama masa perkawinan pertama pada kasus putusan Pengadilan Negeri Jakarta Pusat Nomor 239/Pdt.G/2015/PN.JKT.PST bila dikaitkan dengan penerapan hukum hakim menurut 
peneliti, hakim dalam menerapkan hukumnya tidak melaksanakan tugas pokok dan kewajiban hakim berdasarkan Pasal 50 ayat (1) Undang-Undang Kekuasaan Kehakiman yang telah dijabarkan pada Bab II penelitian ini, karena putusan pengadilan seharusnya memuat alasan dan dasar putusan serta memuat pasal tertentu dari peraturan perundangundang yang bersangkutan atau sumber hukum tak tertulis yang dijadikan dasar untuk mengadili. Selain itu, dalam menyelesaikan suatu perkara hakim pada putusan Pengadilan Negeri Jakarta Pusat Nomor 239/Pdt.G/2015/PN.JKT.PST tidak melakukan penemuan hukum menurut Sudikno Mertokusumo sehingga tidak jelas dalam hal sumber hukumnya apakah berdasarkan peraturan perundang-undangan, hukum kebiasaan, yurisprudensi, atau doktrin seperti yang telah dijelaskan pada Bab II tesis ini.

Selanjutnya peneliti akan menguraikan perihal status dan kedudukan anak baik dari perkawinan pertama maupun dari perkawina kedua. Pengelompokkan anak berdasarkan status dan kedudukannya dihadapan hukum telah dijelaskan dalam Bab II peneilitian. Pada pembahasan tersebut, anak dikelompokkan menjadi 6 (enam) kelompok. Dari keenam kelompok tersebut yang sesuai dengan penelitian ini dan akan dibahas lebih lanjut adalah anak luar kawin.

Pasal 43 ayat (1) Undang-Undang Perkawinan menyebutkan bahwa "Anak yang dilahirkan diluar perkawinan hanya mempunyai hubungan perdata dengan ibunya dan keluarga ibunya"14. D.Y. Witanto berpendapat bahwa:

Bunyi pasal tersebut sebenarnya menimbulkan banyak penafsiran karena kalimat “dilahirkan diluar perkawinan" itu sebenarnya mengandung makna seperti apa? Apakah yang dimaksud diluar perkawinan itu adalah suatu kelahiran yang sama sekali tanpa adanya proses perkawinan, misalnya anak yang lahir dari perzinahan, atau juga termasuk dalam pengertian perkawinan yang tidak sah berdasarkan hukum agama sebagaimana disyaratkan oleh ketentuan Pasal 2 ayat (1) Undang-Undang Perkawinan, atau sebenarnya menunjuk pada proses perkawinan yang tidak di daftarkan sesuai dengan Pasal 2 ayat (2)? Tiga keadaan yang disebutkan diatas masing-masing memiliki persoalan hukum yang berbeda, karena jika maksudnya menunjuk pada keadaan yang sama sekali tidak pernah ada perkawinan, maka anak yang lahir dari perkawinan siri tidak boleh digolongkan anak luar kawin, karena kelahiran anak tersebut dilahirkan dalam atau sebagai akibat dari perkawinan yang sah. Jika maksudnya adalah perkawinan yang tidak dicatatkan maka rumusan kalimat Pasal 43 ayat (1) Undang-Undang Perkawinan tersebut menjadi tidak cocok, karena antara

\footnotetext{
${ }^{14}$ Indonesia (a), Op. cit., Pasal 43 ayat (1).
} 
perkawinan dengan pencatatan merupakan dua hal yang berbeda walaupun yang satu memberikan pengaruh bagi yang lain. ${ }^{15}$

Pasal 43 ayat (2) Undang-Undang Perkawinan menyebutkan bahwa "kedudukan anak tersebut ayat (1) di atas selanjutnya akan diatur dalam peraturan pemerintah" ${ }^{16}$, namun sampai dengan saat ini pemerintah belum juga mengeluarkan peraturan pemerintah tentang kedudukan anak luar kawin. Sementara PP Pelaksanaan Perkawinan tidak mengatur tentang kedudukan anak luar kawin, sehingga sampai sekarang persoalan tentang kedudukan anak luar kawin pengaturannya masih belum jelas karena Pasal 43 ayat (1) Undang-Undang Perkawinan hanya menyebutkan tentang hubungan keperdataanya saja sedangkan terhadap hak-haknya yang harus dilindungi sebagai seorang manusia tidak mendapat pengaturan yang jelas dan terperinci.

Sebagai akibat dari hubungan perdata dengan pihak ibu dan keluarga dari ibunya, anak tersebut hanya akan mendapatkan hak waris dari ibu dan keluarganya saja, termasuk segala bentuk pemeliharaan sampai anak itu dewasa hanya menjadi tanggung jawab ibunya. Sekilas saja ketentuan tersebut mengandung ketidakadilan bagi si ibu dan anaknya, karena untuk membenihkan anak tersebut dalam rahim ibunya pasti ada peran dari pihak laki-laki sebagai ayah biologisnya. Lalu karena si ayah tidak mengakui atau tidak kawin dengan si perempuan itu, maka hubungan keperdataannya menjadi terputus dengan si ayah, padahal hubungan hukum tersebut sangat diperlukan oleh si anak untuk bisa menuntut hak pemeliharaan yang wajar seperti halnya anak-anak yang lain pada umumnya.

Syarat seorang anak luar kawin untuk bisa mendapatkan hak waris dari orang tua bilogisnya menurut hukum perdata barat yaitu KUHPerdata sebagaimana diatur dalam Pasal 862 KUHPerdata yang berbunyi “jika si meninggal anak-anak luar kawin yang telah diakui dengan sah, maka warisan harus dibagi dengan cara yang ditentukan dalam empat pasal berikut" ${ }^{17}$, maka apabila anak luar kawin tersebut telah diakui oleh orang tua biologisnya berhak mendapatkan warisan karena KUHPerdata menganut prinsip bahwa hanya mereka yang mempunyai hubungan keperdataan dengan si pewaris saja yang berhak mewaris. Hubungan hukum antara anak luar kawin dengan ayah atau ibunya timbul setelah adanya pengakuan dari ayah dan ibunya tersebut, dalam arti bahwa hubungan hukum itu

\footnotetext{
${ }^{15}$ D.Y Witanto, Op. cit., hlm.142-147

${ }^{16}$ Indonesia (a), Op. cit., Pasal 43 ayat (2).

${ }^{17}$ R. Subekti dan R. Tjitrosudibio, Op. cit., hlm. 229.
} 
hanya ada antara anak luar kawin yang telah mendapat pengakuan dengan ayah atau ibu yang mengakuinya saja. ${ }^{18}$

Bila dikaikan dengan kasus pada putusan Pengadilan Negeri Jakarta Pusat Nomor 239/Pdt.G/2015/PN.JKT.PST dalam pertimbangan majelis hakim seperti yang telah dijabarkan dalam Bab III penelitian ini, bahwa anak-anak dari Isteri pertama dengan Pewaris yang terdiri dari (1) Rudy Djajasiaputra, (2) Rosana Rijadi, (3) Inneke Riyadi, dan (4) Vonny Riady adalah anak yang diakui sah. Hal ini terbukti sesuai dengan Akta Kelahiran masing-masing keempat anak tersebut terdapat catatan pinggir yang menyatakan bahwa dengan kata pengakuan yang dibuat oleh Buniarti Tjandra, S.H., Notaris di Jakarta tanggal 30 Maret 1983 keempat anak tersebut telah diakui oleh Surya Riyadi (Sia Peng Hoa) dan Cecilia Winny Wiardi (Tjia, Siok Kwan) sebagai anak mereka sendiri. Dengan demikian keempat anak pewaris dengan isteri pertama berhak mendapatkan harta warisan dari pewaris yang pembagian harta warisnya diatur menurut KUHPerdata mengingat perkawinan pewaris dilakukan secara katolik dan anak-anak pewaris menganut Agama Katolik.

Menurut peneliti, anak-anak dari perkawinan kedua pewaris dengan Tergugat I yang terdiri dari: Tergugat II dan Tergugat III tidak dapat dikatakan anak sah walaupun kedua anak tersebut tercatat dalam kutipan akta kelahiran yang dikeluarkan oleh Pegawai Luar Biasa Pencatat Sipil, namun bila dilihat dari tanggal kelahiran Tergugat II dan Tergugat III yang lahir jauh sebelum perkawinan terjadi. Perkawinan kedua pewaris terjadi pada tanggal 22 Juli 1980, yang tercatat pada Pencatatan Sipil di Jakarta Kutipan Akta Perkawinan No. 2321/1980 tertanggal 22 Juli 1980 yang dikeluarkan oleh Pegawai Luar Biasa Pencatat Sipil Jakarta, dan dilegalisir di Pengadilan Negeri Jakarta Timur tertanggal 23 Juli 1980 dibawah register No. 67/TIM/Leg/1980. Sementara itu Tergugat II lahir pada tanggal 30 November 1973 berdasarkan Kutipan Akta Kelahiran Nomor 111/A/1981 tanggal 14 April 1981 dan Tergugat III lahir pada tanggal 4 Juni 1975 berdasarkan Kutipan Akta Kelahiran Nomor 111/B/1981. Oleh karena itu baik Tergugat II maupun Tergugat II dapat dikatakan sebagai anal yang lahir sebelum perkawinan dilakukan.

Berdasarkan uraian analisa penulis diatas, sudah seharusnya perkawinan antara Pewaris dengan isteri pertamanya yang didaftarkan di Kantor Catatan Sipil walaupun perkawinan tersebut dilakukan sebelum disahkannya Undang-Undang Perkawinan, agar

\footnotetext{
${ }^{18}$ Surini Ahlan Sjarif dan Nurul Elmiyah. Hukum Kewarisan Perdata Barat. Cet-II. (Jakarta: Kencana Media Group), hlm. 87.
} 
perkawinan tersebut menjadi tercatat secara sah menurut hukum. Dan dapat memberikan status yang lebih jelas kepada keempat anaknya sebagai anak sah yang diakui dari perkawinan yang sah menurut hukum yang akan berakibat pula kepada hak waris mereka menurut hukum perdata.

Sedangkan perkawinan kedua antara Pewaris dengan isteri Tergugat I yang dilakukan sah secara hukum, sudah seharusnya hakim dalam hal ini mengkaji ulang tanggal kelahiran anak-anak sebelum perkawinan kedua dilakukan agar dapat memberikan status yang lebih jelas kepada kedua anaknya yang lahir sebelum perkawinan dilakukan sebagai anak luar kawin dan berakibat pula kepada hak waris mereka menurut hukum perdata.

Perkawinan yang terjadi pasti akan menimbulkan akibat hukum bagaimana kedudukan anak yang dilahirkan dalam perkawinan tersebut, lalu apakah anak-anak dalam perkawinan tersebut dapat ditarik sebagai ahli waris dan berhak mendapatkan harta peninggalan pewaris.

Dalam hal pembagian harta warisan yang dimiliki Pewaris kepada seluruh ahli warisnya, maka peneliti melakukan pembandingan antara hasil perhitungan dari putusan hakim dengan perhitungan berdasarkan pembagian waris secara perdata karena sesungguhnya mengenai pembagian waris Agama Katolik berpatokan dengan hukum secara perdata.

Perhitungan majelis hakim, bila dikaitkan dengan hukum waris perdata yang berpedoman pada KUHPerdata menurut peneliti ada perbedaan pembagian harta warisnya terutama para ahli waris yang merupakan anak pewaris dari perkawinan dengan isteri kedua. Hal ini dilihat dari perkawinan yang menurut peneliti belum dapat dikatakan sebagai perkawinan sah karena walaupun perkawinan mereka didaftarkan di Kantor Catatan Sipil tapi perkawinan tersebut terjadi didalam perkawinan. Sehingga anak-anak dari perkawinan tersebut dapat dikatakan sebagai anak luar kawin.

Adapun pembagian waris untuk status anak luar kawin apabila diakui oleh kedua orang tuanya sesuai dengan Pasal 863 (1) KUHPerdata yang berbunyi: "Jika yang meninggal meninggalkan keturunan yang sah atau seorang suami atau istri, maka anakanak luar kawin mewarisi sepertiga dari bagian yang mereka sedianya harus mendapatnya andai kata mereka anak-anak yang sah". Oleh karena itu, menurut penulis pembagian harta waris sudah sepatutnya berbeda sesuai dengan harta peninggalan yang menjadi hak ahli waris.

Mengenai harta benda dalam perkawinan yang telah dijabarkan pada Bab II sebelumnya bila dikaitkan dengan kasus, peneliti berpendapat bahwa dari ketiga 
perkawinan yang terjadi dapat diketahui dengan jelas harta benda yang menjadi harta bersama pewaris dengan isteri pertama, isteri kedua dan isteri ketiga. Pada perkawinan pertama, pewaris dengan isteri pertama memperoleh harta bersama berupa SHM No. 37/Perigi atas nama pewaris sesuai Akta Jual Beli No. 129/4/Ciledug/JB/1986 tertanggal 2 September 1976 yang dibuat dihadapan Ronny Harunsyah Gunawan, S.H., Pejabat Pembuat Akta Tanah di Tangerang. Hal ini terbukti bila dilihat tanggal Akta Jual Beli yang dilakukan setelah perkawinan pertama dilangsungkan dan isteri pertama masih hidup.

Selanjutnya pada perkawinan kedua pewaris dengan isteri kedua memperoleh harta bersama berupa:

1. SHM No. 374/Sukajaya atas nama pewaris sesuai Akta Jual Beli No. 696/2012 tertanggal 29 Desember 2012 yang dibuat dihadapan Irmayanti, S.H., Pejabat Pembuat Akta Tanah di Bogor;

2. SHM No. 375/Sukajaya atas nama pewaris sesuai dengan Akta Jual Beli tertanggal 1 Juni 2012 yang dibuat dihadapan Irmayanti, S.H., Pejabat Pembuat Akta Tanah di Bogor; dan

3. SHM No. 375/Sukajaya atas nama pewaris sesuai dengan Akta Jual Beli No. 363/2011 tertanggal 20 September 2011 yang dibuat dihadapan Irmayanti, S.H., Pejabat Pembuat Akta Tanah di Bogor

hal ini terbukti bila dilihat dari ketiga tanggal Akta Jual Beli yang dilakukan setelah perkawinan pertama putus karena meninggalnya istri pertama. Namun apakah harta benda tersebut benar-benar milik isteri kedua, hal inilah yang selanjutnya menjadi analisis penulis.

Harta benda perkawinan menurut Undang-Undang Perkawinan yang telah dibahas pada Bab II menyatakan bahwa menurut pendapat Wahyono Darmabrata, pada hakekatnya harta benda dalam perkawinan meliputi harta yang dibawa ke dalam perkawinan oleh suami-isteri dan harta yang diperoleh sepanjang perkawinan berlangsung. Menurut Pasal 35 ayat 1 menyebutkan bahwa harta yang diperoleh sepanjang perkawinan berlangsung termasuk ke dalam harta bersama, sedangkan menurut Pasal 35 ayat (2) harta yang dibawa ke dalam perkawinan oleh suami-isteri termasuk ke dalam harta bawaan.

Bila dikaitkan dengan kasus, maka menurut penulis harta benda pewaris yang terdiri dari SHM No. 374/Sukajaya, SHM No. 375/Sukajaya dan SHM No. 375/Sukajaya bukan merupakan harta benda dalam perkawinan pewaris dengan Tergugat I. Ketiga harta benda tersebut memang diperoleh pewaris sepanjang perkawinan dengan Tergugat I, namun menurut penulis perkawinan kedua pewaris dengan Tergugat I tidak sah sesuai dengan 
beberapa alasan yang telah penulis uraikan sebelumnya. Jadi penulis berpendapat bila perkawinan kedua tersebut tidak sah, maka ketiga harta benda pewaris tersebut bukan merupakan harta bersama pewaris dengan Tergugat I.

Harta benda pewaris selain 4 (empat) benda tetap yang telah disebutkan sebelumnya, terdapat 1 (satu) benda tetap berupa tanah dan bangunan di Ciputra, Sidoarjo Jawa Timur yang menurut keterangan Tergugat I harta benda tersebut milik Penggugat I sesuai dengan pernyatan pewaris sebelum meninggal untuk diberikan kepada Penggugat I selaku isteri ketiga pewaris. Selain kelima benda tetap yang menajadi harta peninggalan pewaris adalah berupa surat berharga dalam bentuk saham atas nama pewaris di PT. Jombang Agung Riyadi. Harta peninggalan pewaris berupa tanah dan bangunan di Jawa Timur dan berupa surat berharga dalam bentuk saham tidak akan di analisis oleh peneliti dengan alasan bahwa:

1. Tentang harta peninggalan berupa tanah dan bangunan di Jawa Timur tidak jelas kapan perolehannya, sehingga tidak dapat ditentukan pula harta peninggalan pewaris tersebut merupakan harta benda dalam perkawinan pewaris dengan siapa.

2. Tentang harta peninggalan surat berharga dalam bentuk saham juga tidak dapat ditentukan harta peninggalan pewaris tersebut merupakan harta benda dalam perkawinan pewaris dengan siapa karena tidak diketahui kapan pendirian PT. Jombang Agung Riyadi tersebut.

Selain anak luar kawin, perlu diperhatikan pula kedudukan isteri ketiga sebagai ahli waris dalam kedudukannya terhadap pembagian harta peninggalan pewaris yang menjadi objek sengketa waris mengingat bahwa perkawinan pewaris dengan isteri ketiga tersebut terjadi pada tanggal 30 Desember 2011. Hal tersebut berarti bahwa harta peninggalan atas SHM No. 37/Perigi, SHM No. 374/Sukajaya, SHM No. 375/Sukajaya dan SHM No. 16/Sukaluyu bukan harta bersama yang diperoleh pewaris dengan isteri ketiga. Bila dikaitkan dengan fakta pada putusan perkara Pengadilan Negeri Jakarta Pusat Nomor 239/Pdt.G/2015/PN.JKT.PST, yang mana isteri ketiga sudah mendapatkan sebidang tanah dan bangunan yang terletak dan dikenal umum di Jalan Citra Indah Blok C.10, Ciputra, Kabupaten Sidoarjo, Jawa Timur, maka penggugat I pada dasarnya hanya memperoleh apa yang telah diberikan oleh pewaris dan memperoleh bagiannya dari harta peninggalan berupa saham. Pembagian saham yang diperoleh Penggugat I didasarkan dengan perolehan saham tersebut yang dimiliki pewaris sejak tanggal 15 Oktober 2012 artinya diperoleh pewaris selama berlangsungnya perkawinan dengan isteri ketiga. 
Perihal permasalahan kedudukan hak dan status anak dari perkawinan kedua yang terjadi selama masa perkawinan pertama pada kasus putusan Pengadilan Negeri Jakarta Pusat Nomor 239/Pdt.G/2015/PN.JKT.PST bila dikaitkan dengan penerapan hukum hakim menurut penulis, hakim dalam menerapkan hukumnya tidak melaksanakan tugas pokok dan kewajiban hakim berdasarkan Pasal 50 ayat (1) Undang-Undang Kekuasaan Kehakiman khususnya huruf d dan huruf e yang telah dijabarkan pada Bab II tesis ini, karena tidak menggali dan memahami nilai-nilai yang hidup di masyarakat khususnya yang beragama Katolik dan tidak memuat alasan dan dasar putusan yang memuat pasal tertentu dalam peraturan perundang-undangan atau sumber hukum tak tertulis mengenai kedudukan hak dan status anak. Selain itu, dalam menyelesaikan suatu perkara hakim pada putusan Pengadilan Negeri Jakarta Pusat Nomor 239/Pdt.G/2015/PN.JKT.PST tidak melakukan penemuan hukum menurut Sudikno Mertokusumo sehingga tidak jelas dalam hal sumber hukumnya apakah berdasarkan peraturan perundang-undangan, hukum kebiasaan, yurisprudensi, atau doktrin seperti yang telah dijelaskan pada Bab II tesis ini.

\section{Pertimbangan Hukum Majelis Hakim Dalam Kasus Putusan Nomor 239/Pdt.G/2015/PN.JKT.PST Yang Mengabulkan Gugatan Penggugat Menurut}

\section{Hukum Yang Berlaku}

Telah dibahas pada Bab II bagian sub bab kerangka teori bahwa penelitian ini menggunakan teori kepastian hukum menurut Gustav Radbruch sebagai grand theory yaitu yang menyatakan 3 (tiga) nilai identitas yaitu (1) asas kepastian hukum (rechmatigheid) yang meninjau dari sudut yuridis; (2) asas keadilan hukum (gerectigheit) yang meninjau dari sudut filosofis; dan (3) asas kemanfaatan hukum (zwechmatigheid) atau doelmatigheid atau utility, yang meninjau dari sudut sosiologis yang kemudian diralat dengan menempatkan tujuan keadilan diatas tujuan hukum yang lain. Teori kepastian hukum Gustav Radbruch tersebut akan disandingkan dengan teori keadilan menurut Aristoteles khususnya keadilan komutatif yaitu keadilan yang berhubungan dengan persamaan yang diterima oleh setiap orang tanpa melihat jasa-jasanya. Intinya menekankan pada kesamaan bagi tiap orang tanpa membeda-bedakan antara satu dengan yang lain.

Mengenai penerapan hukum majelis hakim haruslah diawali dengan pemahaman mengenai tugas pokok hakim seperti yang telah dibahas pada Bab III. Menurut Pasal 11 ayat (1) Undang-Undang Kekuasaan Kehakiman tugas pokok hakim pada hakikatnya adalah menerima, memeriksa, mengadili, memutuskan dan menyelesaikan setiap perkara yang diajukan kepadanya. Tugas pokok dan kewajiban hakim dalam bidang peradilan yang terdapat pada Undang-Undang Kekuasaan Kehakiman seperti yang telah dibahas pada Bab 
III yang sesuai dengan penelitian ini harus berdasarkan pada Pasal 4 ayat (2), Pasal 5 ayat (1) dan Pasal 50 ayat (1).

Roscoe Pond menyatakan bahwa "seorang hakim pada saat mengadili suatu perkara di pengadilan harus melakukan beberapa langkah, yaitu menemukan hukum, menafsirkan hukum dan menerapkan hukum." 19

Untuk dapat menyelesaikan suatu perkara hakim harus terlebih dahulu mengetahui secara objektif tentang duduk perkara sebenarnya, yang akan diketahui melalui proses pembuktian. Kemudian setelah peristiwa konkrit dibuktikan maka harus dicari hukumnya. Dengan kata lain hakim mulai melakukan penemuan hukum ${ }^{20}$ seperti pendapat Sudikno Mertokusumo yang menyatakan bahwa penemuan hukum lazimya diartikan sebagai proses pembentukan hukum oleh hakim, atau petugas-petugas hukum lainnya yang diberi tugas melaksanakan hukum terhadap peristiwa-peristiwa hukum konkrit, atau merupakan konkritisasi dan individualisasi peraturan hukum (das sollen) yang bersifat umum dengan mengingat peristiwa konkrit (das sein) tertentu. ${ }^{21}$

Sumber penemuan hukum adalah sumber atau tempat terutama bagi hakim dapat menemukan hukumnya. Sumber penemuan hukum terdiri dari "peraturan perundangundangan, hukum kebiasaan, yurisprudensi, perjanjian internasional, dan doktrin". ${ }^{22}$

Berkaitan dengan metode penemuan hukum menurut Achmad Ali, ada 2 (dua) teori penemuan hukum yang dapat dilakukan oleh hakim dalam praktik peradilan, yaitu melalui metode interpretasi atau penfsiran dan melalui metode konstruksi. ${ }^{23}$

Berdasarkan uraian teori diatas bila dikaitkan dengan kasus pada putusan Pengadilan Negeri Jakarta Pusat Nomor 239/Pdt.G/2015/PN.JKT.PST dalam pertimbangan majelis hakim seperti yang telah dijabarkan dalam Bab III penelitian ini maka majelis hakim dalam hal memberikan pertimbangan hukum tidak memahami tujuan hukum yang dapat memberikan kepastian dan keadilan menurut Gustav Radbruch.

Pertimbangan hukum yang dinyatakan oleh majelis hakim tentang status sahnya kedua anak dari perkawinan kedua sangat tidak berdasarkan pada fakta yang terjadi, walaupun kedua anak tersebut telah memiliki Kutipan Akta Kelahiran pada tahun 1981

\footnotetext{
${ }^{19}$ Ahmad Rifai, Penemuan Hukum Oleh Hakim, Cetakan Ke-3, (Jakarta: Sinar Grafika, 2014), hlm. 8.

${ }^{20}$ Sudikno Mertokusumo (a), Hukum Acara Perdata Indonesia, Cet. Ke-8, (Yogyakarta: Liberty, 2009), hlm. 201-202.

${ }^{21}$ Ibid, hlm.10.

${ }^{22}$ Sudikno Mertokusumo (b), Penemuan Hukum Sebuah Pengantar, Cet. Ke-1. (Yogyakarta: Cahaya Atma Pustaka, 2014), hlm. 63.

${ }^{23}$ Ahmad Rifai, Op.cit., hlm. 59.
} 
namun faktanya mereka lahir sebelum perkawinan orang tuanya terjadi. Oleh karena itu dalam hal ini majelis hakim belum dapat memahami nilai-nilai hukum dan menerapkan rasa keadilan terhadap ahli waris lain karena pembagian harta peninggalan dilakukan sama rata tidak sesuai dengan hukum yang berlaku. Majelis hakim seharusnya dapat menyadari bahwa pembagian yang sama rata belum tentu adil.

\section{KESIMPULAN}

Berdasarkan uraian-uraian yang telah disampaikan sebelumnya, penulis telah mendapatkan beberapa simpulan, yaitu sebagai berikut:

1. Kepastian dan akibat hukum terhadap kedudukan ahli waris dalam perkawinan menurut perspektif hukum positif pada kasus putusan nomor 239/Pdt.G/2015/PN.JKT.PST belum tercapai kepastian hukum dan berakibat dengan ketidaksesuaian kedudukan ahli waris pada perkawinan kedua yang seharusnya menjadi anak luar kawin walaupun perkawinan yang dilakukan oleh kedua orangtuanya dinyatakn sah secara hukum karena tercatat pada kantor pencatatan sipil berdasarkan Kutipan Akta Perkawinan yang ada.

2. Pertimbangan hukum majelis hakim dalam kasus putusan nomor 239/Pdt.G/2015/PN.JKT.PST menyatakan sahnya perkawinan kedua yang terjadi selama masa perkawinan pertama akan menimbulkan akibat hukum terhadap kedudukan anak yang dilahirkan dalam perkawinan kedua tersebut sebagai anak yang dilahirkan di luar perkawinan menurut Undang-Undang Perkawinan yang dilahirkan di luar perkawinan hanya mempunyai hubungan keperdataan dengan ibunya dan keluarga ibunya saja. Maka anak-anak dari perkawinan kedua tidak berhak mewaris mengingat harta warisan merupakan harta peninggalan pewaris dari ayahnya yang selanjutnya akan berakibat kepada pembagian waris.

\section{DAFTAR PUSTAKA}

\section{Buku}

Bistaman. Tinjauan Yuridis Pembagian Waris Bagi Ahli Waris Yang Berbeda Agama dengan Pewaris ditinjau dari Hukum Islam dan Hukum Perdata.

Mamudji, Sri. et. al. Metode Penelitian dan Penulisan Hukum. Cet. Ke-1. Jakarta. Badan Penerbit Fakultas Hukum Universitas Indonesia. 2005.

Mertokusumo, Sudikno (a). Hukum Acara Perdata Indonesia. Cet. Ke-8. Yogyakarta. Liberty. 2009. 
Mertokusumo, Sudikno (b). Penemuan Hukum Sebuah Pengantar. Cet. Ke-1. Yogyakarta. Cahaya Atma Pustaka. 2014.

Nawawi, Hadari. Metode Penelitian Sosial. Yogyakarta. Gadjah Mada University Press. 2007.

Rifai, Ahmad. Penemuan Hukum Oleh Hakim. Cetakan Ke-3. Jakarta. Sinar Grafika. 2014. Sjarif, Surini Ahlan dan Nurul Elmiyah. Hukum Kewarisan Perdata Barat. Cet-II. Jakarta. Kencana Media Group.

Subekti, R dan R. Tjitrosudibio. Kitab Undang-Undang Hukum Perdata. Jakarta. PT. Pradya Paramita. 2006.

Sutantio, Retno Wulan. Wanita dan Hukum, Bandung. Alumni. 1979.

Witanto, D. Y. Hukum Keluarga. Hak Dan Kewajiban Anak Luar Kawin Pasca Keluarnya Putusan MK Tentang Uji Materiil UU Perkawinan. Jakarta. Prestasi Pustaka Publisher. 2012.

Yamin dan Utji Sri Wulan Wuryandari. Nukilan. Metode Penelitian Hukum. Jakarta. Universitas Pancasila. 2014.

\section{Peraturan Perundang-Undangan}

Indonesia (a). Undang-Undang Republik Indonesia tentang Perkawinan. UU No. 1 Tahun 1974 LN Tahun 1974.

Indonesia (b). Peraturan Pemerintah Republik Indonesia tentang Pelaksanaan Pengangkatan Anak. PP No. 54 Tahun 2007 LN Tahun 2017 No. 123. TLN No. 4768. 